\title{
Synthesis and X-ray Crystal Structure of a Stable cis-1,2-bis(diphenylphosphino)ethene Monodentate Thiolate Platinum Complex and TGA Studies of its Precursors
}

\author{
Rodrigo H. Vaz ${ }^{a}$, Rosalice M. Silva ${ }^{a *}$, Joseph H. Reibenspies ${ }^{b}$ and Osvaldo A. Serra ${ }^{c}$ \\ ${ }^{a}$ Departmento de Química, Universidade Federal de Minas Gerais, 30190-130, Belo Horizonte - MG, Brazil \\ ${ }^{b}$ Department of Chemistry, Texas A\&M University, College Station, Texas 77843, USA \\ ${ }^{c}$ Departamento de Química, Faculdade de Filosofia Ciências e Letras de Ribeirão Preto, Universidade de São Paulo, \\ 14040-91, Ribeirão Preto - SP, Brazil
}

\begin{abstract}
O complexo de $\mathrm{Pt}(\mathrm{II})\left[\mathrm{Pt}(\mathrm{SPh})_{2}(\mathrm{dppen})\right]$ (4), (dppen, $\mathrm{Ph}_{2} \mathrm{PCH}=\mathrm{CHPPh}_{2}$ ), estável, foi obtido de $\left[\mathrm{PtCl}(\mathrm{SPh})_{2}\left(\mathrm{SnPh}_{3}\right) \operatorname{cod}\right](\mathbf{1})\left(\operatorname{cod}=1,5\right.$-ciclooctadieno), por eliminação redutiva de $\mathrm{SnClPh}_{3} \mathrm{e}$ substituição do ligante cod pela difosfina, porém em baixo rendimento. Contudo, quando $\left[\mathrm{Pt}(\mathrm{SPh})_{2} \mathrm{cod}\right]$ (3) foi utilizado como material de partida, 4 foi obtido em rendimento de $80 \%$. A viabilidade dessas reações foi sugerida por estudos de TG dos materiais de partida. O complexo 4 foi caracterizado por espectroscopia de RMN multinuclear $\left({ }^{195} \mathrm{Pt},{ }^{31} \mathrm{P},{ }^{1} \mathrm{H} \mathrm{e}{ }^{13} \mathrm{C}\right)$, IV e análise elementar. A estrutura molecular de 4, resolvida por um estudo de difração de raios X, exibe geometria quadrática plana ligeiramente distorcida e distâncias de ligação $\mathrm{C}=\mathrm{C}$ e $\mathrm{Pt}-\mathrm{P}$ pequenas, o que foi interpretado em termos de uma interação $\pi$ entre a ligação dupla e a ligação metal-ligante, de acordo com dados descritos na literatura.
\end{abstract}

The stable $\mathrm{Pt}(\mathrm{II})$ complex $\left[\mathrm{Pt}(\mathrm{SPh})_{2}(\mathrm{dppen})(4),\left(\mathrm{dppen}, \mathrm{Ph}_{2} \mathrm{PCH}=\mathrm{CHPPh}_{2}\right)\right.$ was obtained from $\left[\mathrm{PtCl}(\mathrm{SPh})_{2}\left(\mathrm{SnPh}_{3}\right) \operatorname{cod}\right](\mathbf{1})(\mathrm{cod}=1,5$-cyclooctadiene $)$ by reductive elimination reaction of $\mathrm{SnClPh}_{3}$ and substitution of the cod ligand by the diphosphine, albeit in low yields. Yields of $80 \%$ were obtained when $\left[\mathrm{Pt}(\mathrm{SPh})_{2} \mathrm{cod}\right](3)$ was used as the starting material instead. The viability of these reactions was suggested by a TG study, performed on the starting materials. Complex $\mathbf{4}$ was characterized by multinuclear NMR $\left({ }^{195} \mathrm{Pt},{ }^{31} \mathrm{P},{ }^{1} \mathrm{H}\right.$ and $\left.{ }^{13} \mathrm{C}\right)$ and IR spectroscopies and elemental analysis. The molecular structure, solved by an X-ray diffraction study, exhibted a slightly distorted square-planar geometry and short $\mathrm{C}=\mathrm{C}$ and $\mathrm{Pt}-\mathrm{P}$ bond distances which were interpreted in terms of $\mathrm{a} \pi$ interaction between the double bond and the metal-ligand bond, as observed for other diphosphine compounds described previously.

Keywords: platinum, thiolate, phosphine, TG analysis, X-ray crystallography

\section{Introduction}

Pt(II) complexes containing both phosphine and sulfur ligands are described in the literature as presenting luminescent properties. ${ }^{1}$ However, those containing both a monodentate phosphine and a thiolate ligands are described as being unstable, as they undergo polymerization. ${ }^{2,3}$ The most stable ones are those that possess two monodentate phosphines and a bidentate thiolate, or both bidentate thiolate and phosphine ligands. ${ }^{2}$

We have been interested in platinun monometallic and heterobimetallic complexes contaning thiolate ligands,

\footnotetext{
*e-mail: rosalice@apolo.qui.ufmg.br
}

and have recently obtained the complexes shown in Figure $1 .^{4}$

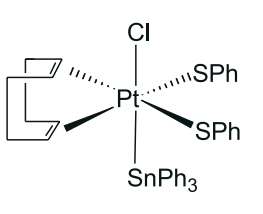

1

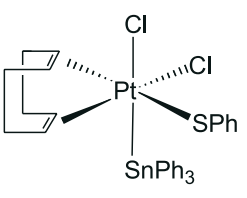

2

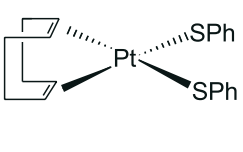

3
Figure1. Monometallic and heterobimetallic platinum thiolate complexes under investigation.

$\mathrm{Pt}$ (IV) complexes related to $\mathbf{1}$ and $\mathbf{2}$ were reported to undergo reductive elimination of $\mathrm{SnClR}_{3}$ to originate the corresponding Pt(II) compounds. ${ }^{3,5}$ If $\mathbf{1}$ and $\mathbf{2}$ presented 


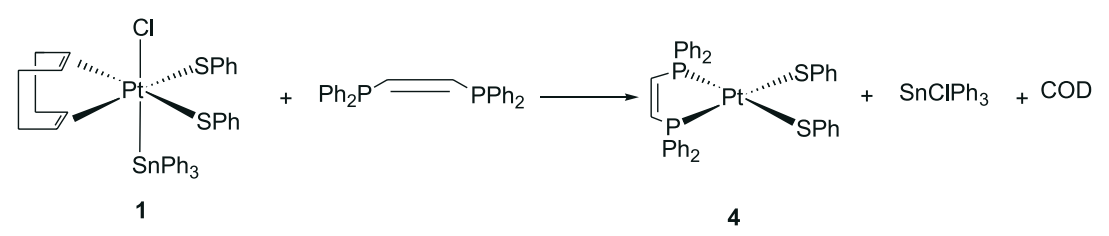

Scheme 1.

the same type of behavior, they would be usefull starting materials for the type of complex we were planning to prepare, especially from complex $\mathbf{1}$, upon reaction with dppen $\left(\right.$ dppen $\left.=\mathrm{Ph}_{2} \mathrm{PCH}=\mathrm{CHPPh}_{2}\right)$, as represented (Scheme1).

We therefore set up to prepare a $\mathrm{Pt}(\mathrm{II})$ complex containing a bidentate phosphine and monodentate thiolate ligands in order to verify if such a compound would exhibit luminescent properties and if it would be stable. In this study we wish to report the synthesis, characterization by spectroscopic methods and the molecular structure of complex $\mathbf{4}$ determined by an X-ray diffraction study. We also report TGA studies, performed on $\mathbf{1}, \mathbf{2}$ and $\mathbf{3}$, in order to determine if $\mathbf{1}$ and $\mathbf{2}$ would undergo reductive elimination of $\mathrm{SnClPh}_{3}$ and if the three compounds would loose the cod ligand.

\section{Experimental}

\section{General considerations}

All operations were carried out under pure $\mathrm{N}_{2}$, using Schlenk and vacuum techniques. $\mathrm{N}_{2}$ was predried over an in line columm consisting of molecular sieves, calcium chloride and calcium sulfate. Hexane and toluene were distilled from sodium/benzophenone. Acetone was distilled over barium oxide. All solvents were used immediately following distillation or stored under nitrogen over the appropriate molecular sieves. $\left[\mathrm{Pt}(\mathrm{SPh})_{2} \mathrm{cod}\right]^{5}(\mathbf{3}),\left[\mathrm{Pt}(\mathrm{Cl})(\mathrm{SPh})_{2}\left(\mathrm{SnPh}_{3}\right) \mathrm{cod}\right]$ (1), ${ }^{5}\left[\mathrm{Pt}(\mathrm{Cl})_{2}(\mathrm{SPh})\left(\mathrm{SnPh}_{3}\right) \operatorname{cod}\right](2),{ }^{5} \mathrm{Ph}_{3} \mathrm{SnSPh}^{6}$ and $\mathrm{Ph}_{2} \mathrm{Sn}(\mathrm{SPh})_{2}^{6}$ were prepared according to procedures described in the literature. dppen was purchased from Strem and used without further purification. Infrared spectra were recorded on a Perkin-Elmer 283 spectrophotometer scanning between 4000 and $200 \mathrm{~cm}^{-1}$, using CsI plates. ${ }^{1} \mathrm{H}$ NMR $(400 \mathrm{MHz}$, $\mathrm{CDCl}_{3}$, standard $\left.\mathrm{SiMe}_{4}\right),{ }^{13} \mathrm{C}\left\{{ }^{1} \mathrm{H}\right\} \mathrm{NMR}\left(100 \mathrm{MHz}, \mathrm{CDCl}_{3}\right.$, standard $\left.\mathrm{SiMe}_{4}\right),{ }^{31} \mathrm{P}\left\{{ }^{1} \mathrm{H}\right\}$ NMR $\left(80 \mathrm{MHz}, \mathrm{CDCl}_{3}\right.$, standard $\left.\mathrm{H}_{3} \mathrm{PO}_{4}\right)$ and ${ }^{195} \mathrm{Pt}\left\{{ }^{1} \mathrm{H}\right\} \mathrm{NMR}\left(86 \mathrm{MHz}, \mathrm{CDCl}_{3}\right.$, standard $\mathrm{K}_{4} \mathrm{PtCl}_{4}$ ) spectra were recorded on a Brucker instrument. $\mathrm{C}, \mathrm{H}, \mathrm{N}$ analyses were performed using a Perkin-Elmer PE-2400 CHN microanalyser. Atomic absorption for platinum was performed on a Hitachi Z-8200 Polarized Zeeman Atomic Absorption Spectrophotometer. TG analyses was performed on a Mettler Termobalance TG 50 of TA 4000 System, at a flow rate of $10{ }^{\circ} \mathrm{C} \mathrm{min}^{-1}$, in alumina cells.

Preparation of $\left[\mathrm{Pt}(\mathrm{SPh})_{2}(\right.$ dppen $\left.)\right](4)$

(a) In a Schlenck flask were loaded $0.19 \mathrm{~g}(0.50 \mathrm{mmol})$ of dppen and $0.25 \mathrm{~g}(0.50 \mathrm{mmol})$ of $\mathbf{3}$ in $20 \mathrm{~mL}$ of toluene. Immediatelly after the addition of the solvent the reaction mixture turned yellow. It was left under reflux for $2 \mathrm{~h} 15 \mathrm{~min}$. After this time it was let to cool to room temperature and a yellow solution was obtained. Upon addition of $20 \mathrm{~mL}$ of hexane a yellow solid precipitated. Yield: $31 \mathrm{mg}, 88 \%$. (b) The same procedure was followed using 1 as the starting material. Yield: $12 \mathrm{mg}, 30 \%$, mp $101.6-105.0^{\circ}\left(\mathrm{CH}_{2} \mathrm{Cl}_{2}\right)$. IR $v_{\text {max }} / \mathrm{cm}^{-1} 3020 \mathrm{~s}, 2985 \mathrm{~m}, 2970 \mathrm{~m}, 1570 \mathrm{~s}, 1425 \mathrm{~s}, 735 \mathrm{~s}$, 700s, 660s, 530s, 315w, 295w. ${ }^{1} \mathrm{H}$ NMR $\left(400 \mathrm{MHz}, 25^{\circ} \mathrm{C}\right.$, $\left.\mathrm{CDCl}_{3}\right) \delta$ 7.77-6.98 (m, 4 $\left.\mathrm{C}_{6} \mathrm{H}_{5}\right), 6.69(\mathrm{~d}, \mathrm{HC}=\mathrm{CH}), 6.68(\mathrm{~d}$, $\mathrm{HC}=\mathrm{CH}) .{ }^{13} \mathrm{C} \mathrm{NMR}\left(400 \mathrm{MHz}, 25^{\circ} \mathrm{C}, \mathrm{CDCl}_{3}\right): \delta 133.86-$ 126-53 (m, $\left.\mathrm{C}_{6} \mathrm{H}_{5}\right), 122.59(\mathrm{Br}, \mathrm{CH}=\mathrm{CH}) .{ }^{195} \mathrm{Pt} \mathrm{NMR}$ $\left(400 \mathrm{MHz}, 25^{\circ} \mathrm{C},\left(\mathrm{CD}_{3}\right)_{2} \mathrm{CO}\right): \delta-4816 \mathrm{~Hz}(\mathrm{t}) .{ }^{31} \mathrm{P} \mathrm{NMR}$ $\left(400 \mathrm{MHz}, 25^{\circ} \mathrm{C}, \mathrm{CDCl}_{3}\right): \delta 53.83\left(\mathrm{~s},{ }^{1} J(\mathrm{PtP}) 3578 \mathrm{~Hz}\right)$. Elemental analysis Found: C, 55.7; H, 3.12. Calc. for $\mathrm{PtC}_{38} \mathrm{H}_{32} \mathrm{P}_{2} \mathrm{~S}_{2}: \mathrm{C}, 56.31 ; \mathrm{H}, 3.95 \%$. Atomic absorption for platinum Found: 27.97. Calc. 24.08 .

Crystallographic structure determination of $\left[\mathrm{Pt}(\mathrm{SPh})_{2}{ }^{-}\right.$ (dppen)] (4)

The structure of complex $\mathbf{4}$ was solved at the Crystal \& Molecular Structure Laboratory, Center for Chemical Characterization and Analysis at Texas A\&M University. Crystallographic data is listed in Table 1. A yellow crystal of $\mathbf{4}$ was mounted on a glass fiber with epoxy cement at room temperature. Preliminary examination and data collection were performed on a Siemens R3M X-ray diffractometer. Cell parameters were calculated from the least-squares fitting of the setting angles for 25 reflections with $2 \theta>2.18$. Lorentz and polarization corrections were applied to 5741 reflections. A total of 5484 unique reflections were used in further calculations. The structure was solved by direct methods using SHELXS-97. ${ }^{7}$ All esd (except the esd in the dihedral angle between two 1.s. planes) are estimated using the full covariance matrix. The 
Table 1. Crystal data and structure refinement for $\left[\mathrm{Pt}(\mathrm{SPh})_{2}(\mathrm{dppen})\right]$ (4).

\begin{tabular}{ll}
\hline Formula & $\mathrm{C}_{38} \mathrm{H}_{32} \mathrm{P}_{2} \mathrm{PtS}_{2}$ \\
Formula weight & 809.79 \\
Crystal system & Monoclinic \\
Space group & $\mathrm{C} 2 / \mathrm{c}$ \\
$\mathrm{a}(\AA)$ & $19.168(4)$ \\
$\mathrm{b}(\AA)$ & $28.197(6)$ \\
$\mathrm{c}(\AA)$ & $14.237(3)$ \\
$\beta\left({ }^{\circ}\right)$ & $119.21(3)$ \\
$\mathrm{V}\left(\AA^{3}\right)$ & $6717(2)$ \\
$\mathrm{Z}$ & 8 \\
$\mathrm{Radiation}(\lambda, \AA)$ & $\mathrm{Mo}, \mathrm{K} \alpha(0.71073)$ \\
$\mu\left(\mathrm{mm}^{-1}\right)$ & 4.424 \\
Temp. $(\mathrm{K})$ & $295(2)$ \\
$\mathrm{D}_{\text {calc }}\left(\mathrm{Mg} \mathrm{m}^{-3}\right)$ & 1.602 \\
$\mathrm{Crystal}$ dimens.(mm) & $0.80 \times 0.40 \times 0.40$ \\
$\mathrm{~T}\left(\right.$ max.,min $\left.^{-3}\right)$ & $0.9062,0.6584$ \\
$2 \theta$ range $\left({ }^{\circ}\right)$ & $2.43-25.02$ \\
Reflections collected & 6173 \\
Independent reflections $\left(\mathrm{R}_{\text {in }}\right)$ & $5900[\mathrm{R}$ int-0.0319] \\
Refinnement method & Full-matrix least square on $\mathrm{F}^{2}$ \\
Data/restraints/parameters & $5900 / 36 / 443$ \\
Goodness-of-fit on $\mathrm{F}^{2}$ & 1.012 \\
Final R indices $(\mathrm{I}>2 \sigma(\mathrm{I})$ & $\mathrm{R} 1=0.0389 ;$ wR2 $=0.0740$ \\
$\mathrm{R}$ indices(all data) & $\mathrm{R} 1=0.0610 ;$ wR2 $=0.0828$ \\
\hline
\end{tabular}

cell esd are taken into account individually in the estimation of esds in distances, angles and torsion angles; correlations between esds in cell parametrs are only used when they are defined by crystal symmetry. An approximate (isotropic) treatment of cell esds was used for estimating esds involving 1.s. planes. A total of 4149 reflections were used for refinement. The structure was refined using SHELXL-97. ${ }^{7}$ The weighted R-factor $w R$ and goodness of fit $\mathrm{S}$ are based on $\mathrm{F}^{2}$, conventional $\mathrm{R}$-factors $\mathrm{R}$ are based on
$\mathrm{F}$, with $\mathrm{F}$ set to zero for negative $\mathrm{F}^{2}$. The threshold expression of $\mathrm{F}^{2}>2 \sigma\left(\mathrm{F}^{2}\right)$ is used only for calculating $\mathrm{R}$ factors ( $\mathrm{gt}$ ) etc. and is not relevant to the choice of reflections for refinement. $\mathrm{R}$ - factors based on $\mathrm{F}^{2}$ are statistically about twice as large as those based on F, and $\mathrm{R}$-factors based on all data will be even larger.

\section{Results and Discussion}

TG analyses in air (Figure 2) of complexes 1, 2 and $\mathbf{3}$ indeed indicated that the former two could reductively eliminate $\mathrm{SnClPh}_{3}$ and that all three could also eliminate the cod ligand (Table 2).

The thermal stability of the complexes decreases in the follwoing order: $\mathbf{3}>\mathbf{2}>\mathbf{1}$. For complexes $\mathbf{2}$ and $\mathbf{3}$ the

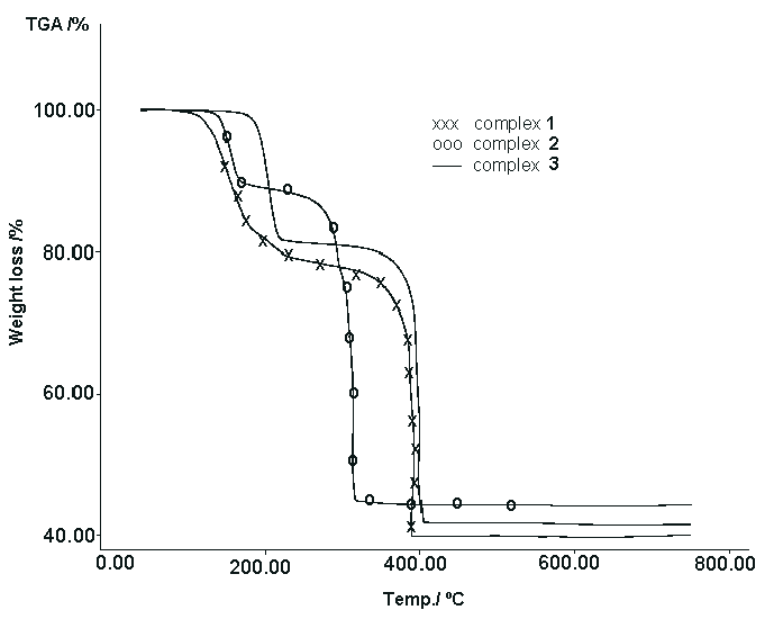

Figure 2. TGA curves for $\left[\mathrm{Pt}(\mathrm{Cl})(\mathrm{SPh})_{2}\left(\mathrm{SnPh}_{3}\right) \operatorname{cod}\right]$ (1), $\left[\mathrm{Pt}(\mathrm{Cl})_{2}(\mathrm{SPh})\left(\mathrm{SnPh}_{3}\right) \operatorname{cod}\right](\mathbf{2})$ and $\left[\mathrm{Pt}(\mathrm{SPh})_{2} \mathrm{cod}\right](\mathbf{3})$.

Table 2. TGA results for complexes $\left[\mathrm{Pt}(\mathrm{Cl})(\mathrm{SPh})_{2}\left(\mathrm{SnPh}_{3}\right) \operatorname{cod}\right](\mathbf{1}),\left[\mathrm{Pt}(\mathrm{Cl})_{2}(\mathrm{SPh})\left(\mathrm{SnPh}_{3}\right) \operatorname{cod}\right](\mathbf{2})$ and $\left[\mathrm{Pt}(\mathrm{SPh})_{2} \mathrm{cod}\right](\mathbf{3})$.

\begin{tabular}{|c|c|c|c|c|c|}
\hline Complex & $\mathbf{T}\left({ }^{\circ} \mathbf{C}\right)$ & $\operatorname{Obs}(\%)$ & $\begin{array}{l}\text { Weight loss } \\
\text { Calc(\%) }\end{array}$ & Interpretation & Product, e.a. \\
\hline \multirow[t]{2}{*}{1} & $\begin{array}{l}28.7-223.0 \\
\text { (onset-124.0) }\end{array}$ & 24.22 & 25.82 & Loss of COD and $2 \mathrm{CH}_{2} \mathrm{Cl}_{2}$ & $\begin{array}{l}{\left[\mathrm{Pt}(\mathrm{Cl})(\mathrm{SPh})_{2}\left(\mathrm{SnPh}_{3}\right)\right]} \\
\text { Found: } \mathrm{C}, 45.09 \% ; \mathrm{H}, 3.80 . \\
\text { Calc. for } \mathrm{C}_{30} \mathrm{H}_{25} \mathrm{PtSnS}{ }_{2} \mathrm{Cl}: \mathrm{C}, 45.08 ; \mathrm{H}, 3.13 \% \text {. }\end{array}$ \\
\hline & $223.0-395.3$ & 36.51 & 35.81 & Loss of $\mathrm{SnClPh}_{3}$ & $\begin{array}{l}{\left[\mathrm{Pt}(\mathrm{SPh})_{2}\right]} \\
\text { Found: } \mathrm{C}, 36.83 ; \mathrm{H}, 2.31 \text {. } \\
\text { Calc. for } \mathrm{C}_{12} \mathrm{H}_{10} \mathrm{PtS}_{2} \mathrm{Cl}: \mathrm{C}, 34.86 ; \mathrm{H}, 2.42 \% \text {. }\end{array}$ \\
\hline \multirow[t]{2}{*}{2} & $\begin{array}{l}76.3-190.0 \\
\text { (onset-127.0) }\end{array}$ & 12.46 & 10.03 & Loss of COD & $\begin{array}{l}{\left[\mathrm{PtCl}_{2}(\mathrm{SPh})\left(\mathrm{SnPh}_{3}\right)\right]} \\
\text { Found: } \mathrm{C}, 43.60 ; \mathrm{H}, 3.11 \%) \\
\text { Calc. For } \mathrm{C}_{24} \mathrm{H}_{20} \mathrm{PtSnSCl}_{2}: \mathrm{C}, 39.74 ; \mathrm{H}, 2.78 \% \text {. }\end{array}$ \\
\hline & $\begin{array}{l}\text { 190.0-380.7 } \\
\text { (onset-292.0) }\end{array}$ & 43.17 & 42.01 & Loss of $\mathrm{SnClPh}_{3}$ & {$[\mathrm{Pt}(\mathrm{Cl})(\mathrm{SPh})]$} \\
\hline \multirow[t]{2}{*}{3} & $\begin{array}{c}94.3-255.7 \\
\text { (onset-180.0) }\end{array}$ & 18.90 & 20.65 & Loss of COD & $\begin{array}{l}{\left[\mathrm{Pt}(\mathrm{SPh})_{2}\right]} \\
\text { Found: C, } 35.29 ; \mathrm{H}, 2.48 \\
\text { Calc. for } \mathrm{C}_{12} \mathrm{H}_{10} \mathrm{PtS}_{2}: \mathrm{C}, 34.86 ; \mathrm{H}, 2.42 \% \text {. }\end{array}$ \\
\hline & $\begin{array}{l}255.7-400.7 \\
\text { (onset-376.0) }\end{array}$ & 39.41 & 41.68 & Loss of $\mathrm{PhSSPh}$ & Pt metal \\
\hline
\end{tabular}


first decomposition step originated one stable intermediate, but complex 1 decomposed in more than one intermediate. The decomposition of the three complexes occured in the $120.0^{\circ}-400.0^{\circ} \mathrm{C}$ temperature range. For 1 , the first stage of decomposition could correspond to the elimination of the cod ligand or of PhSSPh. However, the IR spectrum of the residue, taken after this stage of decomposition, together with the elemental analysis, revealed that cod had been eliminated to give $\left[\mathrm{PtCl}(\mathrm{SPh})\left(\mathrm{SnPh}_{3}\right)\right]$. The absorption bands of the cod ligand, observed in the IR spectrum of complex 1, at 3040, 3000, 2940 and $1470 \mathrm{~cm}^{-1}$ could no longer be observed. In the second stage, reductive elimination of $\mathrm{SnClPh}_{3}$ was observed with formation of $\left[\mathrm{Pt}(\mathrm{SPh})_{2}\right]$, according to elemental analysis. Complex 2 behaved similarly to $\mathbf{1}$, but $\mathrm{SnClPh}_{3}$ was lost at a lower temperature. The composition of the residue after the loss of cod from 2 was $\left[\mathrm{Pt}(\mathrm{Cl})_{2}(\mathrm{SPh})\left(\mathrm{SnPh}_{3}\right)\right]$ and after the loss of $\mathrm{SnClPh}_{3},[\mathrm{Pt}(\mathrm{Cl})(\mathrm{SPh})]$. For 3, in the first stage of the decomposition, elimination of the cod ligand occured, as for 1 , but at a slightly higher temperature to give $\left[\mathrm{Pt}(\mathrm{SPh})_{2}\right]$. In the second stage elimination of the thiophenolate unit $\mathrm{SPh}_{2}$ was observed. X-ray powder diffractograms of the final residues, of all the complexes heated at $750{ }^{\circ} \mathrm{C}$, showed that Pt metal is formed as the final product of the thermolysis, together with an amorphos material, Figure 3.

\section{Synthesis and characterization of $\mathbf{4}$}

Complex 4 was first obtained from the reaction of $\mathbf{3}$ and dppen in toluene, in $80 \%$ yield. Reaction in dichloromethane resulted in poor yield. When 1 was used as the starting material, 4 was obtained in only $30 \%$ yield, Scheme 2.

Yellow complex $\mathbf{4}$ is air stable and soluble in commom organic solvents. In the ${ }^{1} \mathrm{H}$ NMR spectrum the olefin

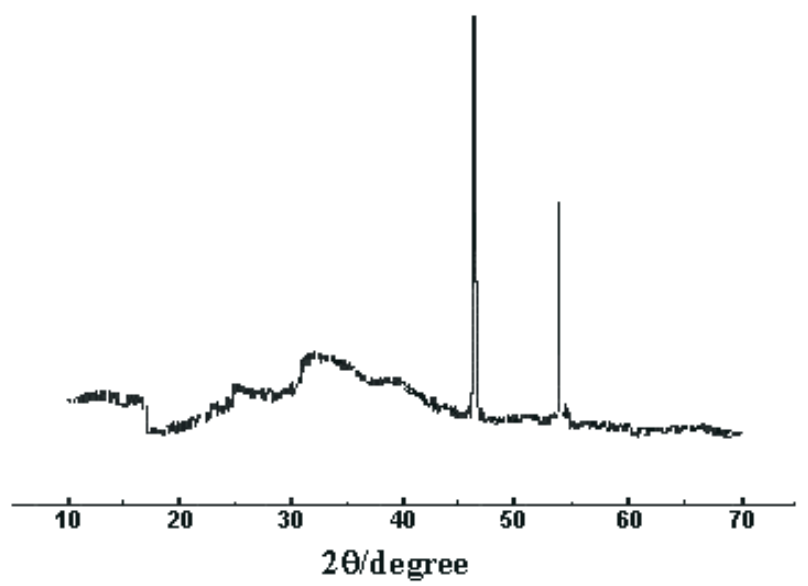

Figure 3. X-ray diffractogram of the residue from the thermolysis of complex 3 .

hydrogens were observed as doublets at $\delta 6.69$ and 6.68 . In the ${ }^{31} \mathrm{P}$ NMR spectrum the dppen phosphorus appeared as a singlet at $\delta 53.63$ together with the $\mathrm{Pt}$ satellites. The ${ }^{1} \mathrm{~J}$ $(\mathrm{Pt}, \mathrm{P})$ value of $3576 \mathrm{~Hz}$ is very close to those reported for related complexes containing the dppen ligand described in the literature. ${ }^{8}$

\section{Solid-state structural data}

Good quality crystals of complex 4 were obtained from an acetone solution that was left at room temperature for a few days. A single crystal X-ray diffraction study of $\mathbf{4}$ established its structure. An ORTEP view of the molecular structure and the adopted numbering scheme are shown in Figure 4. Table 1 gives details of the crystal structure determination. Selected bond angles and distances are listed in Table 3. The structure shows a monomeric neutral complex in which the Pt(II) center has a slightly distorted square-planar geometry, as a consequence of the chelate five-ring constraining the $\mathrm{P}(1)-\mathrm{Pt}-\mathrm{P}(2)$ angle to $86.49(4)^{\circ} .^{8-11}$

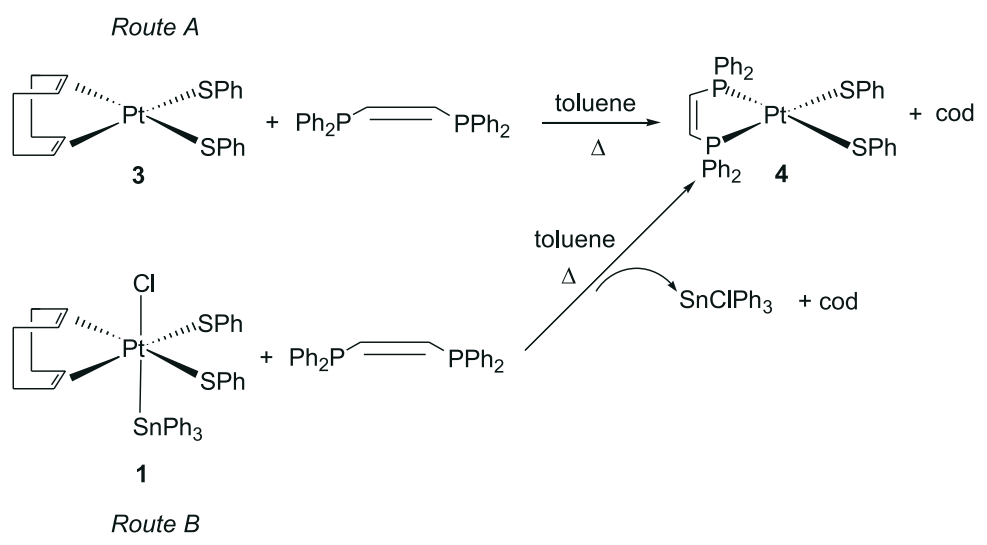

Scheme 2. 


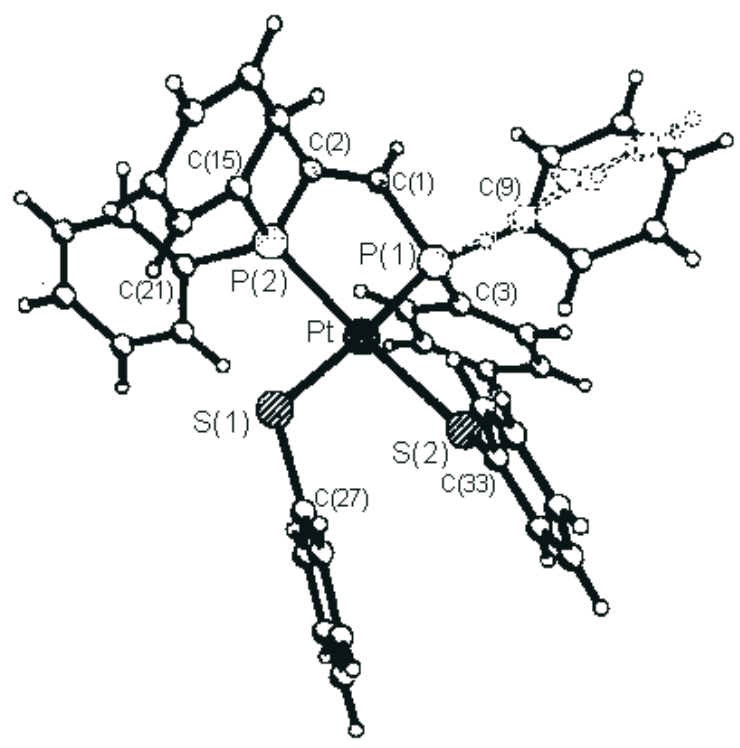

Figure 4. Atom arrangements and numbering scheme for $\left[\mathrm{Pt}(\mathrm{SPh})_{2}(\right.$ dppen $\left.)\right](4)$. Probality ellipsoids drawn at $30 \%$.

Table 3. Selected bond lengths and angles for $\left[\mathrm{Pt}(\mathrm{SPh})_{2}(\mathrm{dppen})\right](4)$.

\begin{tabular}{llll}
\hline \multicolumn{4}{c}{ Bond lengths $(\AA)$} \\
\hline $\mathrm{Pt}(1)-\mathrm{P}(1)$ & $2.2362(18)$ & $\mathrm{P}(1)-\mathrm{C}(3)$ & $1.810(7)$ \\
$\mathrm{Pt}(1)-\mathrm{P}(2)$ & $2.2462(18)$ & $\mathrm{P}(1)-\mathrm{C}(9)$ & $1.840(2)$ \\
$\mathrm{Pt}(1)-\mathrm{S}(1)$ & $2.3560(2)$ & $\mathrm{P}(1)-\mathrm{C}(1)$ & $1.815(7)$ \\
$\mathrm{Pt}(1)-\mathrm{S}(2)$ & $2.3611(17)$ & $\mathrm{P}(2)-\mathrm{C}(21)$ & $1.807(7)$ \\
$\mathrm{C}(1)-\mathrm{C}(2)$ & $1.309(10)$ & $\mathrm{P}(2)-\mathrm{C}(15)$ & $1.808(8)$ \\
$\mathrm{P}(2)-\mathrm{C}(2)$ & $1.806(8)$ & $\mathrm{P}(1)-\left(9^{\prime}\right)$ & $1.826918)$ \\
\hline \multicolumn{5}{c}{ Bond angles $\left(^{\circ}\right)$} \\
$\mathrm{P}(1)-\mathrm{Pt}(1)-\mathrm{P}(2)$ & $86.49(4)$ & $\mathrm{C}(2)-\mathrm{P}(2)-\mathrm{Pt}(1)$ & $107.15(3)$ \\
$\mathrm{P}(1)-\mathrm{Pt}(1)-\mathrm{S}(1)$ & $175.29(7)$ & $\mathrm{C}(21)-\mathrm{P}(2)-\mathrm{Pt}(1)$ & $118.10(2)$ \\
$\mathrm{P}(2)-\mathrm{Pt}(1)-\mathrm{S}(1)$ & $89.25(7)$ & $\mathrm{P}(2)-\mathrm{Pt}(1)-\mathrm{S}(2)$ & $173.21(7)$ \\
$\mathrm{P}(1)-\mathrm{Pt}(1)-\mathrm{S}(2)$ & $87.34(6)$ & $\mathrm{P}(1)-\mathrm{Pt}(1)-\mathrm{S}(1)$ & $175.29(7)$ \\
$\mathrm{S}(1)-\mathrm{Pt}(1)-\mathrm{S}(2)$ & $87.00(7)$ & $\mathrm{C}(2)-\mathrm{P}(2)-\mathrm{Pt}(1)$ & $107.50(3)$ \\
$\mathrm{C}(1)-\mathrm{P}(1)-\mathrm{Pt}(1)$ & $107.77(3)$ & $\mathrm{C}(9)-\mathrm{P}(1)-\mathrm{Pt}(1)$ & $123.40(8)$ \\
$\mathrm{C}(3)-\mathrm{P}(1)-\mathrm{Pt}(1)$ & $115.7(2)$ & $\mathrm{C}\left(9^{\prime}\right)-\mathrm{P}(1)-\mathrm{Pt}(1)$ & $114.20(8)$ \\
\hline
\end{tabular}

The P(2)-Pt-S(1) [89.25(7) ${ }^{\circ}$ and $\mathrm{P}(1)-\mathrm{Pt}-\mathrm{S}(2)\left[87.34(6)^{\circ}\right]$ angles are very close to the ideal angles for this geometry. The trans angles, $\mathrm{P}(1)-\mathrm{Pt}-\mathrm{S}(1)\left[175.29(7)^{\circ}\right]$ and $\mathrm{P}(2)-\mathrm{Pt}-\mathrm{S}(2)$ $\left[173.21(7)^{\circ}\right]$ are smaller than the ideal. The Pt-P

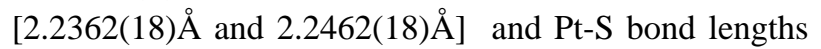
[2.3560(2) and 2.3611(17) $\mathrm{\AA}]$ are comparable to bond distances in similar complexes that have trans phosphorus and sulfur ligands. ${ }^{912,13}$ The dppen $\mathrm{C}=\mathrm{C}$ bond distance in 4 is $1.309(10) \AA$, shorter than an ideal aliphatic double bond lenght of 1.377(7) $\AA$. In the related complex cis$\left[\mathrm{PtCl}_{2}(\mathrm{dppen})\right]^{8}$ complex the $\mathrm{C}=\mathrm{C}$ bond distance was found to be 1.315(5) $\AA$. Diphosphine complexes that exhibit short $\mathrm{C}=\mathrm{C}$ and Pt-P bond lengths, such as the above mentioned, are described as presenting a $\pi$ bonding interation between the double bond and the metal-ligand bond. ${ }^{8,14,15}$ In some cases this leads to completely planar structures, although in other cases deviation from the coplanarity is observed, due to crystal packing effect as found in the two crystal modifications of $c i s$ - $\left[\mathrm{PtCl}_{2}\right.$ (dppen) $] .^{8,15} \mathrm{In}$ one of them the square-planar coordination of the platinum atom is slighttly distorted ${ }^{8}$ and in the other one it is completely planar. ${ }^{13}$ In spite of the change from complete to partial coplanarity in these two crystalline forms, the $\pi$ bond interaction is maintained. The data obtained for complex 4 can be interpreted similarly to the former case.

\section{Conclusions}

The results obtained from the TG analyses of complexes 1 and 3 indicated that the cod ligand and $\mathrm{SnClPh}_{3}$ in the former complex, could be substituted under relatively easy conditions. Complex $\mathbf{4}$ was therefore obtained from both $\mathbf{1}$ and $\mathbf{3}$, although the yield of the reaction of complex $\mathbf{3}$, as the starting material, was much higher, $88 \%$. Complex 4 , with a bidentate phosphine and a monodentate thiolate ligand, is quite stable, similarly to other complexes that possess either monodentate phosphines and a bidentate thiolate ligand or bidentate phosphine and thiolate ligands. ${ }^{2} \mathrm{~A} \pi$-bond interaction between the double bond and the metal-ligand bond is responsible for the short $\mathrm{C}=\mathrm{C}$ and Pt-P bond distances ${ }^{8}{ }^{814,15}$ Contrarily to our expectation, attempts to obtain excitation spectra of $\mathbf{4}$, both in the solid state and in solution were not successfull. The spectra were not well-resolved, showed low emission and were very dificult to interpret.

\section{Acknowledgements}

We thank Fapemig and CNPq for financial support and Professor M.Y. Darensbourg of Texas A\&M University for her support.

\section{Supplementary Information}

Supplemenatry Crystallographic data have been deposited with the Cambridge Crystallographic Data Centre as supplementary publication no. CCDC 116149. Copies of available material can be obtained, free of charge, on application to the Director, CCDC, 12 Union Road, Cambridge CH2 1EZ, UK, (fax: +44 1223336033 or e-mail: deposit@ccdc.cam.ac.uk or hppt://www.ccdc.cam.ac.uk).

\section{References}

1. Kaiwar, S. P.; Vodaccek, A.; Blough, N. V.; Pilato, R. S.; J. Am. Chem. Soc. 1997, 119, 3311. 
2. Verkade, J. G.; Fazlur-Rahman, A. K.; Inorg. Chem. 1992, 31,5331 .

3. Rendina, L. M.; Vittal, J. J.; Puddephat, R. J. ; Organometallics 1996, 15, 1749.

4. Vaz, R. H.; Silva, R. M.; Abras, A.; J. Braz. Chem. Soc. 1998, 9, 57.

5. Levy, C. J.; Vittal, J. J. Puddephat, R.; Organometallics 1996, 15,35 .

6. Speziali, N. L.; Guimarães, B. G.; Silva, R. M.; Duarte, P. H.; Aguiar, S. R.; Quím. Nova 1995, 18, 329.

7. Sheldrick, G. M. , SHELXS-97, Program for the Solution of Crystal Structures, Universität Göttingen, 1997.

8. Oberhauser, W.; Bachmann, C. ; Brüggeller, P.; Inorg. Chim. Acta 1995, 238, 35.

9. Iretskii, A.; Adams, H.; Garcia, J. J.; Picazo, G. ; Maitlis, P. M.; Chem. Comm. 1998, 1, 61 .

10. Avis, M. W.; Vrieze, K.; Ernsting, J. M. ; Elsevier, C. J.; Organometallics 1996, 15, 2376.
11. Van der Boom, M. E.; Liou, Shyh-Yeon; Shiman, L. J. W.; Bem-David, Y.; Milstein, P.; Organometallics 1996, 15, 2562.

12. Garcia, J. J.; Mann, B. E.; Adams, H.; Bailey, N. A. ; Maitlis, P. M.; J. Am. Chem. Soc. 1995, 117, 2179.

13. Calligaris, M.; Carturan, G.; Nardin, G.; Scrivanti, A. and Wojcicki, A.; Organometallics 1983, 2, 865.

14. Oberhauser, W.; Bachmann, C.; Stampfl, T.; Haid, R.; Brüggeller, P.; Polyhedron 1997, 16, 2827.

15. Oberhauser, W. ; Bachmann, C.; Stampfl, T. ; Haid, R. ; Langes, C. ; Rieder, A. ; Brüggeller, P.; Inorg. Chim. Acta 1998, 274, 143 .

Received: April 17, 2001

Published on the web: December 10, 2001

FAPESP helped in meeting the publication costs of this article. 